\title{
Erratum to: Relationship between survival and increased radiation dose to subventricular zone in glioblastoma is controversial
}

\author{
Olgun Elicin · Ebrar Inac • Esengul Kocak Uzel • \\ Songul Karacam $\cdot$ Omer Erol Uzel
}

Published online: 11 April 2014

(c) Springer Science+Business Media New York 2014

\section{Erratum to: J Neurooncol}

\section{DOI 10.1007/s11060-014-1424-3}

In the legends of ALL three figures in the original publication, ALL the signs listed below were wrong in ALL places, and should have been the corresponding opposites.

\begin{tabular}{ll}
\hline Wrong & Right \\
\hline$<$ & $\geq$ \\
$>$ & $<$ \\
$\leq$ & $\geq$ \\
$\geq$ & $<$ \\
\hline
\end{tabular}

The online version of the original article can be found under doi:10.1007/s11060-014-1424-3.

O. Elicin · E. Inac $\cdot$ S. Karacam · O. E. Uzel

Radiation Oncology Department, Cerrahpasa Faculty of Medicine, Istanbul University, I.U. Cerrahpasa Tip Fakultesi, Radyasyon Onkolojisi A.D. - Fatih, 34098 Istanbul, Turkey

O. Elicin $(\bowtie)$

Inselspital, Radiation Oncology Department, University of Bern, Inselspital Klinik und Poliklinik für Radio-Onkologie,

3010 Bern, Switzerland

e-mail: olgunelicin@gmail.com

E. K. Uzel

Radiation Oncology Department, Sisli Etfal Teaching Hospital, Sisli Etfal Egitim Arastirma Hastanesi, Radyasyon Onkolojisi Klinigi - Sisli, 34371 Istanbul, Turkey 